and, consequently, opposes the formation of anything like an indentation on the external surface of the gut." Now what do I really say upon circular stricture of the rectum within reach of the finger, the point upon which wo are here at issue? "We sometimes find bands of a firm consistence extending from side to side, form ing septa across the bowel; these septa are most commonly situate towards the inferior part of the gut. Then again, we find the intestine contracted in a circular form, being dilated immcdiately above the contracted part by the perpetual lodgment of feces, in the form of an hour-glass. This is by far the most formidable kind of stricture, simple contraction, as well as the most difficult of alleviation. But the peculiar and morbid changes generally formed in cases of confirmed stricture, appear to be the result of considerable thickening of the bowel, from deposition in the cellular tissue which connects the muscular and mucous coats." *

1 will not comment any further upon these "similar" opinions than to add, that Dr. O'Beirne has a happy knack of noticing what may by possibility be distorted in his favour, and of carefully avoiding what satisfactorily refutes his positions. Thus we find, that of Mr. Cooper's decision of the spasmodic annular stricture (fully proved by Drs. Blundell and Ryan, and Mr. Stanley, to be a case of permanent obstruction), he says, " $M r$. Cooper in a letter to me states, that the contraction is evidently not the change of structure." What, I would ask, have your readers to do with $\mathrm{Mr}$. Cooper's private correspondence with Dr. O'Beirne? It is the former gentleman's recorded opinion we are to be guided by. Then, again, he says, "Mrr. Stanley, under the head of second specimen from a male, is less accurate in his account of this preparation;" thus taking for granted that it was the same Dr. Blundell described under preparation $B$, which it was not, but a second case of circular stricture within reach of the finger. Had Dr. O'Beirne read the description with the slightest attention, he inust have seen this. He likewise carefully avoids alluding to the conclusion of Dr. Ryan's judgment, "From these and the other preparations, I am perfectly convinced of the existence of stricture in every part of the recbum." So also of $\mathrm{Mr}$. Starley's julgment of the third case, he assumes it to have been one of thickening from fistula; unfortunately, however, I can attest to the contrary, having attended the patient from whom the preparation was taken nearly two years before

* Salmon on the Rectum. Fourth edition, p. 22. any fistula occurred with circular strioture, which disease I have reason to suppose was produced from the extreme cold to which he was subjected, while with the expedition to the North Pole, of which expedition he was one of the officers.

I have thus, I believe, exposed the fallacy of Dr. O'Beirne's arguments, shown the untenability of his positions, as well as I trust satisfactorily refuted his accusations. The performance of this disagreeable task has caused me some pain, but the personalities to which my opponent descended, left me no alternative, and I have endeavoured "to perform.it in as respectful and moderate a manner as the circumstances will permit." And now, convinced that your readers, like myself, must be pretty well tired of this controversy, I beg leave to decline extending it under any circumstances whatsoever; gratefully thanking you for the space you have accorded me in the pages of your valuable journal. I remain, Sir,

Your very obedient servant,

Fredertck Satimon.

12, Old Broad Street, Feb. 6, 1834.

\section{Mr. Salmon to Dr. Blundell.}

MY DRAR SIR,-I request you will be so good as to give the bearer (if it is ready), or if not, send me by Monday morning's first post, your opinion on the preparations; $l$ am to send it to the printer's byten o'clock on that day. Mr. Bransby Cooper has sent the one you wrote for him away to O'Beirne, so that I have no means of saving you this additional tronble. I am, my dear Sir, yours, \&c.,

12, Old Broad Street, Nov. 30, 1833. FREDERICK SALYON.

Dr. Blundell in reply.-My dear Salmon, excnse haste.-J.B.- (Opinion returned in my note. -5. 5.)

No. 1.-Mr. Cooper in Reply to a Note of Ivir. Salmon, requesting his Opinion of the P'reparations.

My dear Sir,-I waited for Dr. Blundell's account of you preparations until I was tired, and as I did not like to keep Dr. O'Beirne so long in suspense, I wrote him my opinion of your preparations which $\mathbf{I}$ saw, and have since sent him the paper Dr. Blundell enclosed to me. I kept no copy of my own opinions respecting how far I considered your preparations held out, or, rather, demonstrated your views of stricture of the rectum, but I know that it went against yours, and in fivour of Dr. O'Beirne's ideas upon the subject ; but I will write to $O^{\prime}$ Beirne immedirtely, that I may forward to you my precise words as written unde: the first impression, or if the delay be inconvenient to you, I will write the substance again. Yours, very truly,

(No day or date, but received Nov. 20th, 1833. F.S.)

No. 2.-Mr. Salmon to Mr. Cooper.

12, Old Broad Street, Nov. 20, 1833.

My dear Sir,-I regret that you should have sent your decision to Dr. O'Beirne without my knowledge, and confess $I$ think that in a question so deeply 
involving the interests of the community, onr profession, and iny chan acte:, you onght not fo have done so without first apprizing me of your intention. Neither does it appeat to ne that the reason you assign for having witten to your friend (to wit Dr. Blin dell's delay), altes the cireminstances of the case, since, hat you communicated with me, such delay would have been satisfactorily accomated for. This proceeding is, however, of minor impol tance, compared with the decision you state you have given upon the varions preparations of stricture of the rec tum submitted to your inspection, and which 1 mms now, in justice to myself, hay betore two or three other experienced morbid anatonists, notwithstanding the clear, decisive, and incontrovertible statement, $\mathrm{Dr}$ Blundell forwarded to you of them, and which fully illustiates the fact I publicly pledged mysell to confin. Meanwhile, oblige me by immeshatety writius to Dr. O'Beirne for a copy of your opinion, with the view of my giving it publicity, in conjunction with that of Dr. Blundell, and those of others whom I may hereafter request to inspect the preparations. Apulogizing for giving you so much trouble, I am, my deac sir, yours faithfully,

Frederick Salmox.

\section{No. 3.-Mr. B. Cooper to Mr. Salmon.}

My dear Sir,-As it was impossible that you and Dr. O'Beirne could simultaneonsly recuive the opinion I had formed of your piepdrations, in seference to the point in dispute between you, I camot see why he had not the same right to have it first as you seem to claim to yourself. Yours, very truly,

BRANSBY B. COOPER. F. S.)

(No day or date, but received Nov. 22nd, 1833.-

\section{No. 4.-Mr. Salmon to Mr. B. Cooper.}

12, Old Eroad Streer, Nov. 30, 183:

My dear Sir,-Being pressed for my reply to ive $O$ 'Beirne, I canoot any longer delay it, for the per pose of adding, as I conld have wished, the opinion which you stated in your first note to me you litid forwarded to that gentleman, and which I ratier expected would have arived from Dnblin ele this. I must therefore, in justice to $D_{i}$. O'Btinne, publish our correspondence as illustrative of yom decision. You appear to have mistahen the sense of my last letter; 1 only meant that $I$ thought a copy of you opinion should have been rorwarded to me is rell a to Dr. O'Beirne; this however, it seems, could not be done, since you onitted to take a copy of it. I am, my dear sir, yours, very fithfully,

\section{Fredertuk Salmon.}

\section{No. 5.-Mr. B. Cooper to Mr. Salmon.}

My dear Sir, On enclosing yon this opinion on the subject of your controversy with Dr. O'beirne, 1 must leave it to yourselves to place the issne before the profession; and believe me, that in giving my opinion, I am actuated only by a desire to elicit truth. $I$ have to apologize for not having sent this to you earlier, but I have svished to hase met Dr. Blundell at your house, and have taken the preparations ont of the bottles to examine them more closely. I do not, however, like to withhold iny decision longet, although I should still wish to meet $\mathrm{Dr}$. Blundell with you. Yours, very truly,

BRANSBY B. COOPER.

New Street, Sunday (Dec. 1st, added by $\mathrm{F}$. $\mathrm{S}$.)

\section{No. 6.-Mr. Salmon to Mr. B. Cooper.}

My dear Sir,-I have this moment, while at dinner, received your letter, enclosing an opinion respecting the prepalations. I an mable to say any more (as your servant is waiting) than, that I have sent iny answer to $1 / x$. O'Beime to the Medical Journals, also a letter to you last night, which fully explains why $I$ did so. An 1 to understind that the upinion I now receive is the copy or what you sent to Dublin to Dr. O'Beinne? Be so good as to reply to this question : also say whether yon wish the communication I have ju+t acceived, forwarded to the medical perindicals, in which my reply to your friend is to alpear; I think it $I$ send it before 'Tuesday morning, it may be added. Yours, very truly,

FreDiRICK SA L,HON.

Suuday, December 1-t, quat te $s^{-p a s t} 6$ o'clock.

\section{No. 7.-Mr. B. Conper to Mr. Salmon.}

My dear sir,-With respect to my opinion of your preparations, which 1 lave sent to you, you are at liberty to do with it as you please. $I_{1}$ is what 1 wrote immediately npon seeing your collection, and yol wonlu have had them long since, had not Dr. Blundell becn so tedions in his delay. I therefore sent it to O'Beirne, and now to you, as it was first written. Why yon should wite a letter to me thiough the public journals, when there is a twopenny post, is best known to yourself. I an yours tils Bransey B. CoOper.

New Street, Monday morning.

\section{No. 8.-Mr. Salmon to Mr. B. Cooper.}

12, Old Broad Street, Feb. 4, 1834.

My dear Sir, $-\mathbf{I}$ suppose you conld not have re ceived my note posted on saturday night, wisen you tow warded yours to me of this morning; of, if you had, yon have again sadly misunderstood the sense of it. I have add essed no letter to you throngh the press; all l have clone is to forward our correspond. ence iclative to your judgment of the preparations, a a inatter of satistaction to Dr. O'Bcirne and the profession, an omission of which wonld have rendered my answer to that gentleman incomplete. I will send and stop (it possble) the publication of your correspondence, and atso request that the opinion vesterlay received from you may be innerted in its itterd. I am, my dear Sir, with good feeling, yoms very truly,

Deceniber $2 \mathrm{nd}, 1 \mathrm{s33}$.

\section{No. 9.-Mr. Salmon to Mr. B. Cooper.}

My dear Sir,-I am sorry to be under the necessity of pibliwing the correspondene which pasaed beIween us relative to any controversy with Dr. O'beirne, but the accusations he has thonght proper to make alfecting my character, not only ior consistency, but esen cummon propriety towards you and hinself, have, in my judgment, as well as in that of my friends, rendered this step absolntely neces. saty. I am the mole surprised at the conrse bl. $O$ 'Beime has tahen, since he implicates you by stating that he had the "favourable documents" containing the opinions of yourself and $\mathrm{Dr}$. Blundell "so early as the mulule of last November," but that instearl of "tding any advantage of Mr. Salmon, he, Mr. O'Eeirne, wh ute to Mr. Cooper, and submit ted to him the necessity of slitting the prepardtiuns marked $A$ and 3 , their whole length, bejote either lie or Dr. Llumitl conld taikly cume to it final de cision." Di: O'Beime then atds" "that it would appear that Mr. Cooner was prevented from making this fuir and considerate proposal, or interfering fiurther in the affair, by the step hr. Salmon had taken in the Mris Tris-nanely, requesting Mr. Stanley and Dr. Ryan to inspect his preparations, and give their opinion on the contested points." Now ifie fact is, as you I feel assured will realliy admit, that yonis as nell as Dr. Blundell's opinion was formed and forwaded to Dr. U'Perme some day before 1 wrote to $\mathrm{jon}$, stating that 1 shond lerquest the julgment of smme other individnds, which step took, as ota letter's prove, because you were undble to for ward me yonr decision on the pieparations, hav ing taken no copy of what you had sent to Dr. G'Beirne, but which yon added was in his favour.

You willikewise remember that on coriespondence was gone to the pinter's, with my answer to you fiend, when the copy of your judgment, which you hatl schit for wo bablin, reached ine, and that I stopped the piess to alter my manuscigh, so as to make it 
consiatent with that judgment, and to substitute it for your letters.

Pit so gool as to give me a few lines in reply, stat ing whether the foregoing is not a correct replesenta tion of the facts of the cate, which, if gou wonlal do at your earliest conrenience, I shall be obligeti, so that I may be emabled to give your reply publicity in the journals of baturday next.

In conchusion I repeat my unfoiraed regret for the couse $D_{:}$" $O$ 'Bein ne las compelled me to pursue, and 1 beg to assure yot of the sincere respect and esteen of yous, vely tiaithelly,

FrevLRICK SALMON.

No. 10.-Mi. B. Cooper to hir. Salmon.

My denr Sir,--If you think it necessary, you are pertectlv welcome to publish the correspondence be tween in, relative to the controversy between yourselt and Dr. Beirne. Yours, very truly,

BHANSBY B. COOPER.

2, New Strect, Feb. 5th, 1834.

\section{RICE AND CHOLERA.}

REMARKS, BY DR. TXTLER, ON THE LETTER OF MR. DUNN.

\section{To the Elitor of Tre LANCET.}

Srr,-The letter of Mr. Dunn, published in the last number of TrE LA NCET, contains two facrs of great importance. The first is contained in the following assertion of Mr. Dunn. "In November, in consequence of the circumstances mentioned in my former letter, an alteration in the dietary was made, by which the animal food was reduced; milk, which before was allowed to be purchased, was forbidden, and two ounces of rice were, twice a week, substituted for potatoes." This is followed by the remark, that " the quantity of rice allowed (two ounces twice a week) is too small to have produced any effect." But, Sir, with submission to Mr. Dunn, these are neither the words of his former letter, nor do they convey the inferences which are derlucible from that letter, as corroborated by the facts that are disclosed in the communication under date 4 th instant. The words of his former letter" are these: "We have substituted an allowance of rice, the result of which I will communicate after we have made a longer trial of it." Now, Sir, what is the result? And this information in his last letter is not directly afforded by $\mathrm{Mr}$. Dunn, for he thore states, " the quantity of rice is too small to have produced any effect," and yet in his preceding communication, we were promised to have the " RESULT" of the quantity of rice, small or great, which was given as diet to the prisoners at Wakefield!

Nevertheless this information is amply supplied, although indirectly supplied, in Mr. Dunn's recent epistle, because in it he unequivocally mentions that on the 9th of December, " a case of Asiatic cholera occurred in a vagrant," and that " the disease continued to spread among the vagrants until the morning of the 24 th of January, when it made its appearance in a most alarming form, without any premonitory symptoms, in a different part of the prison." This, Sir, is a most accurate description of rice disease, as it often makes its appearance in those who are using rice, without any warning symptom, and this ideutical effect is thus alluded to in my letter of Nov. 4 th, 1833. "The rice may therefore produce, should it he bad, a deleterious effect on those who partake of it, although the disease thus prodnced may appear to the medical gentlemen in attendance to originate in some other cause." In the Wakefield prison rice was given as food, and continued to be given, and in that prison, while the rice was so given, dreadful bowel complaints, cholera, and other diseases, made their appearance, and this is "THE RESULT" of "THE TRIAL" which has been " made with rice" at Wakefield, as is gathered from Mr. Dunn's own statements, although he says the rice was given only at the rate of two ounces per week.

The second fact alluded to in the letter of Mr. Dunn, which requires notice, is this. Mr. Dunn says, "In many of the samples furnished in Wakefield I detected the varieties of bad rice Dr. Tytler has described." Here, then, in Wakefield, an inland town of Yorkshire in England, the deleterious rice is admitted to be present, and that town has been conspicuous, at least since the discussions on the rice question, for the prevalence of cholera. Those facts speak volumes, and it is, therefore, unnecessary for me to pursue the subject further. I beg to remain, Sir, yours very obediently,

London, February 16th, 1834.

R. Tyther, M.D.

APPIICATION OF

\section{WHITE PAINT TO BURNS AND SCALDS.}

\section{To the Editor of The LANCET.}

Sin,-I have been induced by the suc. cess of the practice, to lay before you a brief account of a mode of treating burns and scalds which I have followed for some time with great and immediate relief to the patient. The application may not be new, but I have not seen it mentioned in any work that I have read upon the subject. 